Errata

\title{
NEW SEX ATTRACTANTS FOR 35 TORTRICID AND 4 OTHER LEPIDOPTEROUS SPECIES, FOUND BY SYSTEMATIC FIELD SCREENING IN THE NETHERLANDS
}

\section{C.J.H. BOOIJ and S. VOERMAN}

Institute for Pesticide Research Marijkeweg 22, 6709 PG Wageningen, The Netherlands

Page 135: in the abstract, Cydia strobilella should be Cydia pactolana.

Page 136: 3rd paragraph, Kydonieus and Beroza should be Inscoe, 1982. Insect attractants pheromones, and related compounds, pp 201-295, in Kydonieus and Beroza (eds) (see references).

Page 137: last paragraph, the following blends should be added: $E$ 8$12: \mathrm{Ac}+E 8-12: \mathrm{OH}(1: 1), E 9-12: \mathrm{Ac}+E 9-12: \mathrm{OH}(1: 1)$, and $Z 10-12: \mathrm{Ac}+$ Z10-12:OH (1:1).

Page 139: in the 8th and 9th line $E 8-12$ :Ac should be $E 7-12$ :Ac, in the 10th and 14th line E7-12:Ac should be E8-12:Ac. In the 2nd paragraph the sentence ... Two other Pammene species ... should be replaced by ... Three other Pammene species, $P$. obsurana, P. populana, and $P$. splendidulana were attracted most to Z8-12:Ac $+Z 8-12: \mathrm{OH}(1: 1)$ or pure Z8-12:OH. In the bottom line Cydia strobilella should be Cydia pactolana.

Page 140: the name Cydia strobilella should be replaced by Pammene splendidulana (Guenée). Of Eulis ministrana 126 males were captured in 2 traps from 5/25-6/15.

Page 141: Petrova resinella was captured with Z9-12:Ac + E9-12:Ac.

Page 143: 1st paragraph, the names Cydia strobilella and Cydia pactolana should be replaced by Pammene populana and P. splendidulana. In the 3rd paragraph + Z9-12:Ac should be inserted between E9-12:Ac and (9:1).

Page 144: the following reference should be inserted: Bradley, J.D., Tremewan, W.G. and Smith, A. 1973. British Tortricid Moths. Vol. I: Cochilidae and Tortricidae: Torticinae. The Ray Society, London.

\section{REFERENCES}

Bool, C.J.H. and Voerman, S. 1984. J. Chem Ecol. 10:135-144. 